\section{Microclimate Prediction for Dynamic Greenhouse Climate Control}

\author{
Oliver Körner ${ }^{1}$, Jesper Mazanti Aaslyng, and Andrea Utoft Andreassen \\ Department of Agricultural Sciences, Crop Science, University of \\ Copenhagen, Hoejbakkegaard Allee 21, 2630 Taastrup, Denmark
}

\author{
Niels Holst \\ Department of Integrated Pest Management, University of Aarhus, \\ Forsoegsvej 1, 4200 Slagelse, Denmark
}

Additional index words. Energy-saving, leaf temperature, optimal climate control, simulation models

\begin{abstract}
Greenhouse energy-saving and biocide reduction can be achieved through dynamic greenhouse climate control with computerized model-based regimes. This can be optimized when next to greenhouse macroclimate (i.e., the aerial environment) also, the crop microclimate is predicted. The aim of this article was to design and apply a simple deterministic microclimate model for dynamic greenhouse climate control concepts. The model calculates crop temperature and latent heat of evaporation in different vertical levels of a dense canopy of potted plants. The model was validated with data attained from experiments on dynamic or nondynamic (regular) controlled greenhouse cultivation. Crop temperature was with a $95 \%$ confidence interval of $2{ }^{\circ} \mathrm{C}$ or $2.4{ }^{\circ} \mathrm{C}$ for sunlit or shaded leaves, respectively, accurately predicted in a simple greenhouse with predefined climate set points. With a more dynamic greenhouse control also including assimilation lighting and screens, the prediction quality decreased but still had a $95 \%$ confidence interval of crop temperature prediction of $3.8^{\circ} \mathrm{C}$ for sunlit leaves. Simulations showed that controlling greenhouse temperature according to the predicted crop temperature rather than according to the air temperature can save energy. Energysaving is highest during winter and $12 \%$ energy saving was attained during January under Danish climate conditions.
\end{abstract}

During the last 20 years, several dynamic temperature regimes were designed for greenhouse energy-saving (e.g., Aaslyng et al., 1999; Bailey, 1985; Bailey and Seginer, 1989; Buwalda et al., 1999; Körner and Challa, 2003a; Seginer et al., 1994). In the early 1990s, a complete dynamic climate control concept was first developed (Aaslyng et al., 2003) and constantly further developed since then. The system aims at optimizing the greenhouse microclimate to ensure maximum net dry matter production, taking energy consumption into consideration (Aaslyng et al., 2003).

It is a component-based system, i.e., it consists of separate software building blocks that can be updated separately and new components can be added easily. Each component handles a biologic, physical, or environmental control task. Next to a component for dynamic temperature control, other climatic control components for, e.g., pests (Jakobsen et al., 2005), diseases (Körner and Holst, 2005), or supplementary assimilation light (Aaslyng et al., 2006, Körner et al. 2006), were developed.

Controlling greenhouse climate dynamically results in fluctuating greenhouse air

Received for publication 29 June 2006. Accepted for publication 5 Dec. 2006.

${ }^{1}$ To whom reprint requests should be addressed; e-mail oli@life.ku.dk.

cooling down, crop temperature can be higher or lower than greenhouse air temperature. As it is the crop temperature that influences crop growth and developmental processes, crop temperature rather than greenhouse air temperature needs to be controlled. In addition, the difference between air and crop temperature and the speed of temperature changes are the keys for many plant diseases (Körner and Challa, 2003b; Körner and Holst, 2005).

Although several approaches were presented to calculate crop temperature from the greenhouse macroclimate (Kempkes and Van de Braak, 2000; Wang and Deltour, 1999; Zhang et al., 1997, 2002), most climate controllers and regimes control the greenhouse air temperature rather than crop temperature. The few approaches to control crop temperature were designed for and tested with nondynamic (i.e., regular) greenhouse temperature regimes only. The few microclimate models for dynamic climate regimes (Boonen et al., 2000; Van Pee et al., 1998) were developed as black box models that are not generically usable. The aim of this work was therefore to develop and apply a simple generic deterministic microclimate model that can be used for dynamic greenhouse climate control. The model should be able to predict crop microclimate from a green- house macroclimate (monitored by commercial climate-measuring equipment). In that way, greenhouse microclimate can be predicted by regular sensors that are located above the crop rather than distributing sensors within the crop.

A model is presented that describes the crop microclimate in a vertical transect of the crop canopy. The model was validated with experimental data from dynamic and regular climate regimes. In a final simulation study, comparisons were made on the effects on energy consumption and crop microclimate by controlling greenhouse temperature either based on ambient greenhouse temperature (belonging to macroclimate) or by crop temperature (belonging to the microclimate) calculated with the presented microclimate model.

\section{Materials and Methods}

Model development. Crop temperature $\left(\mathrm{T}_{\mathrm{c}}, \mathrm{K}\right)$ in different canopy layers $(\mathrm{z})$ was calculated by integrating absorbed irradiative net fluxes $\left(\mathrm{R}_{\mathrm{n}, \mathrm{a}}, \mathrm{W} \cdot \mathrm{m}^{-2}\right)$, boundary layer and stomata resistances $\left(r_{b}\right.$ and $r_{s}$, respectively, $\left.\mathrm{s} \cdot \mathrm{m}^{-1}\right)$, and vapor pressure deficit at the leaf surface $\left(\mathrm{VPD}_{\mathrm{s}}, \mathrm{kPa}\right)$ in the canopy. The extinction of short-wave radiation as it passes through the canopy to heights $\mathrm{z}$ was calculated with the Lambert-Beer's law; z was a function of the leaf area index (LAI) and estimated for three vertical positions in the canopy according to the Gaussian three-point integration procedure (Goudriaan and Van Laar, 1994):

$$
z_{(1,2,3)}=\left\{\begin{array}{l}
0.11 \cdot L A I \\
0.50 \cdot L A I \\
0.89 \cdot L A I
\end{array}\right.
$$

Crop temperature, $\mathrm{T}_{\mathrm{c}}$, was calculated according to Stanghellini (1987):

$$
\begin{aligned}
& T_{c}(z)-T_{a}= \\
& \frac{\frac{1}{\rho_{a} c_{p}}\left(r_{b}(z)+r_{s}(z)\right) R_{n, a}(z)-\frac{1}{\gamma} V P D_{s}(z)}{1+\frac{\delta}{\gamma}+\frac{r_{s}(z)}{r_{b}(z)}+\frac{1}{\rho_{a} c_{p} / 4 \sigma T_{a}{ }^{3}}\left(r_{b}(z)+r_{s}(z)\right)}
\end{aligned}
$$

with greenhouse air temperature $\left(T_{a}, K\right)$, air density $\left(\rho_{\mathrm{a}}, \mathrm{g} \cdot \mathrm{m}^{-2}\right)$, Stefan-Boltzmann constant $\left(\sigma, \mathrm{W} \cdot \mathrm{m}^{-2} \cdot \mathrm{K}^{-4}\right)$, specific heat capacity of the air $\left(\mathrm{c}_{\mathrm{p}}, \mathrm{J} \cdot \mathrm{g}^{-1} \cdot \mathrm{K}^{-1}\right)$, the psychrometric constant $\left(\gamma, \mathrm{Pa} \cdot \mathrm{K}^{-1}\right)$, and the slope between saturated vapor pressure and greenhouse air temperature $\left(\delta, \mathrm{Pa} \cdot \mathrm{K}^{-1}\right)$. Latent heat of evaporation $\left(\lambda \mathrm{E}, \mathrm{W} \cdot \mathrm{m}^{-2}\right)$ in different canopy layers was calculated with Eq. [3]:

$$
\lambda E(z)=\left(\frac{\frac{\delta}{\gamma} R_{n, a}(z)+\frac{\rho_{a} c_{p}}{\gamma}\left(\frac{1}{r_{b}(z)}+\frac{1}{\rho_{a} c_{p} / 4 \sigma T_{a}^{3}}\right) V P D_{s}(z)}{1+\frac{\delta}{\gamma}+\frac{r_{s}(z)}{r_{b}(z)}+\frac{1}{\rho_{a} c_{p} / 4 \sigma T_{a}^{3}}\left(r_{s}(z)+r_{b}(z)\right)}\right)
$$

Too high potential $\lambda \mathrm{E}$ can result in a higher transpiration than plants can handle and then water loss may exceed water uptake 
(Körner and Challa, 2003b). In the opposite case when $\lambda E$ becomes negative, dew will be formed on leaves and other tissues that can lead to plant diseases.

Leaf net absorption of short- and longwave radiation $\left(\mathrm{R}_{\mathrm{n}, \mathrm{a}}, \mathrm{W} \cdot \mathrm{m}^{-2}\right)$ was calculated from incoming solar short wave radiation to the crop $\left(\mathrm{Q}, \mathrm{W} \cdot \mathrm{m}^{-2}\right)$, a factor for leaf absorbance of short-wave radiation (a) and the long-wave radiation exchange between the leaves and the greenhouse $\left(\mathrm{L}_{\mathrm{n}}, \mathrm{W} \cdot \mathrm{m}^{-2}\right)$ (Yu et al., 2001):

$$
R_{n, a}(z)=a Q(z)+L_{n}(z)
$$

Long-wave radiation exchange was calculated for the different horizontal positions in the canopy in accordance to equation developed by Ross (1975). The long-wave radiation exchange was separated into exchanges at the upper and the lower leaf surfaces $\left(\mathrm{L}_{\mathrm{u}}, \mathrm{L}_{\mathrm{d}}, \mathrm{W} \cdot \mathrm{m}^{-2}\right.$, respectively):

$$
\begin{gathered}
L_{n}(z)=L_{d}(z)+L_{u}(z) \\
L_{d}(z)=L_{d}(0)-\tau_{d}(z)\left(L_{d}(0)\right) \\
L_{u}(z)=L_{u}(0)-\tau_{u}(z)\left(L_{u}(0)\right)
\end{gathered}
$$

with penetration functions for downward and upwards long-wave radiation $\left(\tau_{\mathrm{d}}\right.$ and $\tau_{\mathrm{u}}$, respectively); $\mathrm{L}_{\mathrm{d}}(0)\left(\mathrm{W} \cdot \mathrm{m}^{-2}\right)$, and $\mathrm{L}_{\mathrm{u}}(0)$ $\left(\mathrm{W} \cdot \mathrm{m}^{-2}\right)$ are radiation exchanges from lower and upper leaf surfaces at a crop level LAI of 0 (i.e., canopy top). The $\mathrm{L}_{\mathrm{d}}(0)$ and $\mathrm{L}_{\mathrm{u}}(0)$ values were calculated from the long-wave radiation exchange between crop temperature at crop level LAI of $0\left(\mathrm{~T}_{\mathrm{c} 0}, \mathrm{~K}\right)$ or greenhouse surface temperatures $\left(\mathrm{T}_{\mathrm{g}}, \mathrm{K}\right)$, and the greenhouse cover or screen temperature $\left(T_{r}, K\right)$, the Stefan-Boltzmann constant, and emissivities of crop surface, greenhouse cover or screen, and the remaining greenhouse surfaces $\left(\varepsilon_{\mathrm{c} 0}, \varepsilon_{\mathrm{r}}, \varepsilon_{\mathrm{g}}\right.$, respectively, $\left.\mathrm{W} \cdot \mathrm{m}^{-2}\right)$. The effective emissivities between the surfaces $\left(\varepsilon_{\mathrm{c} 0, \mathrm{r}}, \varepsilon_{\mathrm{c} 0, \mathrm{~g}}, \mathrm{~W} \cdot \mathrm{m}^{-2}\right)$ were calculated with a simple relation assuming large parallel surfaces according to Bot and Van de Braak (1995) (Eq. [10]). Greenhouse surface temperatures include heating pipes, tables, soil, and others. For simulations, the initial value of $\mathrm{T}_{\mathrm{c} 0}$ was assumed equal to greenhouse air temperature; in later simulation steps, the calculated crop temperature of the preceding simulation step was used:

$$
\begin{gathered}
L_{d}(0)=\varepsilon_{c 0, r} \cdot \sigma \cdot\left(T_{c 0}^{4}-T_{r}^{4}\right) \\
\begin{aligned}
L_{u}(0)=\varepsilon_{c 0, g} \cdot \sigma \cdot\left(T_{c 0}^{4}-T_{g}^{4}\right) \\
\varepsilon_{c 0, r}=\left(1 / \varepsilon_{c 0}+1 / \varepsilon_{r}\right)^{-1} \\
\varepsilon_{c 0, g}=\left(1 / \varepsilon_{c 0}+1 / \varepsilon_{g}\right)^{-1}
\end{aligned}
\end{gathered}
$$

When artificial assimilation light was used, a term for absorbed heat energy and long-wave radiation produced by the lamps $\left(\mathrm{E}_{\mathrm{AL}}, \mathrm{W} \cdot \mathrm{m}^{-2}\right)$ was added to Eq. [8]:

$$
L_{d}(0)=\varepsilon_{c 0, g} \cdot \sigma \cdot\left(T_{c 0}^{4}-T_{r}^{4}\right)-E_{A L}
$$

The penetration function for downward long-wave radiation, $\tau_{\mathrm{d}}$, as a function of $\mathrm{z}$ was attained by fitting data published by Ross (1975) (fitted parameters c, d, and e: -0.008 , $-0.857,0.046$, respectively; standard error of the estimate 0.005). Because $\mathrm{z}$ is a function of the LAI, $\tau_{\mathrm{d}}$ decreased with increasing LAI:

$$
\tau_{d}(z)=\exp \left(c+d \cdot z+(e \cdot z)^{2}\right)
$$

The penetration function for upwards long-wave radiation, $\tau_{\mathrm{u}}$, was assumed similar to $\tau_{\mathrm{d}} . \mathrm{T}_{\mathrm{r}}$ was either calculated from the four variables greenhouse air temperature, effective sky temperature (Yu et al., 2001), outside temperature, and wind speed outside the greenhouse (De Zwart, 1996); or when available, measured data were used to predict $T_{r}$. $\mathrm{T}_{\mathrm{g}}$ was either assumed to be the same as greenhouse air temperature or measured data were used.

Stomata resistance was calculated from relative humidity at leaf surface $\left(\mathrm{RH}_{1}, \%\right)$, minimum stomata resistance to water vapor at light compensation $\left(\mathrm{r}_{\mathrm{s}, \mathrm{min}}, \mathrm{mol} \cdot \mathrm{m}^{-2} \cdot \mathrm{s}^{-1}\right)$, $\mathrm{CO}_{2}$ partial pressure at the leaf surface $\left(\mathrm{C}_{1}\right.$, $\left.\mu \mathrm{mol} \cdot \mathrm{mol}^{-1}\right)$, an empiric coefficient (j), leaf net assimilation rate $\left(\mathrm{P}_{\mathrm{nl}}, \mu \mathrm{mol} \cdot \mathrm{m}^{-2} \cdot \mathrm{s}^{-1}\right)$, and atmospheric pressure $(\theta, \mathrm{Pa})$ as proposed for potted roses (Ball et al., 1987; Kim and Lieth, $2003) ; \mathrm{k}$ is the conversion factor from $\left[\mathrm{m}^{2} \cdot \mathrm{s} \cdot \mathrm{mol}^{-1}\right]$ to $\left[\mathrm{s} \cdot \mathrm{m}^{-1}\right]$ with 0.025 (Jones, 1992):

$$
r_{s}(z)=\left(r_{s, \min }+j \cdot P_{n l}(z) \frac{R H_{l}}{C_{l}(z) / \theta}\right)^{-1} \cdot k
$$

Leaf net photosynthesis was attained by fitting the negative exponential light response curve (Thornley, 1976) with leaf photochemical efficiency $\left(\alpha_{l},\left[\mathrm{~mol} \mathrm{CO}_{2}\right] \cdot[\mathrm{mol} \text { photons }]^{-1}\right)$ and maximum leaf net photosynthesis $\left(\mathrm{P}_{\mathrm{nl}, \max }, \mu \mathrm{mol} \cdot \mathrm{m}^{-2} \cdot \mathrm{s}^{-1}\right)$ for the different canopy levels $\mathrm{z}$ according to the photosynthetic photon flux $\left(\mathrm{I}_{P P F}, \mu \mathrm{mol} \cdot \mathrm{m}^{-2} \cdot \mathrm{s}^{-1}\right)$ :

$$
P_{n l}(z)=P_{n l, \max } \cdot\left(1-\exp \left(\frac{-\alpha_{l} \cdot I_{\mathrm{PPF}}(z)}{P_{n l, \max }}\right)\right)
$$

Absorbed $\mathrm{I}_{P P F}$ fluxes were calculated separately for diffuse and direct radiation and as a function of $\mathrm{z}$ (Van Kraalingen and Rappoldt, 1989). Leaf photochemical efficiency, $\alpha_{l}$, and $\mathrm{P}_{\mathrm{nl}, \max }$ were calculated based on biochemical leaf photosynthesis models (Farquhar and Von Caemmerer, 1982; Farquhar et al., 1980) and approaches of Gijzen (1994) as shown by Körner (2004). The boundary layer resistances $\left(r_{b}, s \cdot m^{-1}\right)$ for leaves in different crop levels $\mathrm{z}$ were attained from the dimensionless Nusselt number $(\mathrm{Nu})$ and the thermal diffusivity of air $\left(\chi, \mathrm{m}^{2} \cdot \mathrm{s}^{-1}\right)$ as proposed for potted chrysanthemums (Yang, 1995). The Nu number was calculated from the dimensionless Grashof (Gr) and Reynolds (Re) numbers (Stanghellini, 1987):

$$
\begin{gathered}
r_{b}(z)=(\chi \cdot N u(z))^{-1} \\
N u(z)=0.37 \cdot\left(G r(z)+6.92 \cdot \operatorname{Re}(z)^{2}\right)^{0.25}
\end{gathered}
$$

$$
\operatorname{Re}(z)=u(z) \cdot l / v
$$

$$
G r(z)=g \cdot \beta \cdot l^{3} / v^{2} \cdot\left(T_{c}(z)-T_{a}\right)
$$

with air velocity $\left(\mathrm{u}, \mathrm{m} \cdot \mathrm{s}^{-1}\right)$, the characteristic dimension of the leaf surface $(1, \mathrm{~m})$, the kinematic viscosity of air $\left(\mathrm{v}, \mathrm{m}^{2} \cdot \mathrm{s}^{-1}\right)$, acceleration resulting from gravity $\left(\mathrm{g}, \mathrm{m} \cdot \mathrm{s}^{-1}\right)$, and the coefficient of thermal expansion $\left(\beta, \mathrm{K}^{-1}\right)$.

Greenhouse experiments. Two experiments with potted roses were carried out. Expt. 1 was conducted with a $24-\mathrm{h}$ dynamic temperature regime, i.e., temperature was only dynamic within $24 \mathrm{~h}$ and set points were the same for each $24 \mathrm{~h}$. Expt. 1 was a shortterm experiment of 5 weeks ( 8 Nov. -15 Dec. 2004). Roses (Rosa, 'Vanilla Charming Parade') were planted in black plastic pots (8-cm high, $10-\mathrm{cm}$ diameter) filled with a commercial peat mix and were then placed on an ebb and flow table in a research greenhouse compartment $\left(25 \mathrm{~m}^{2}\right)$ at the Danish Institute of Agricultural Sciences (Slagelse, Denmark, $\left.55^{\circ} 18^{\prime} \mathrm{N}\right)$. Plants were placed with a spacing of $10 \mathrm{~cm}$ to all sides. Plants were allowed to grow naturally (no pinching), but plant height was kept at $20 \mathrm{~cm}$ (from pot edge) by periodic cutting with electric scissors. Within each $24-\mathrm{h}$ period, temperature was set to 10,20 , or $24^{\circ} \mathrm{C}: 10^{\circ} \mathrm{C}(0800-1159 \mathrm{HR}$; 2000-2359 HR ), $20^{\circ} \mathrm{C}$ (1200-1759 HR; 0000$0559 \mathrm{HR})$, and $24^{\circ} \mathrm{C}(0600-0759$ HR; 1800 $1959 \mathrm{HR})$. As a result of the relatively large greenhouse surface in relation to the plant canopy, humidity levels were expected to be much lower than in commercial size greenhouses. To attain humidity levels like in commercial practice, the relative humidity $(\mathrm{RH})$ set point was $100 \%$ (i.e., neither heating nor ventilation for dehumidification was used). In addition, a fogging and ventilation system located under the tables distributed water vapor in the greenhouse when RH was lower than $85 \%$. With that procedure, $\mathrm{RH}$ levels with an average of $74 \%$ (ranging between $52 \%$ and $100 \%$ RH, standard deviation $15.3 \% \mathrm{RH}$ ) were attained. Only during some periods, $\mathrm{RH}$ was close to $100 \%$ and no incidences with fungi such as Botrytis were observed before determination of the experiment.

Climate was controlled with a commercial greenhouse climate computer (LCC1200; DGT Volmatic, Odense, Denmark). The vents were closed throughout the complete experiment. Pipe heating was used. An energysaving screen (LS10; Ludvig Svensson, 
Kinna, Sweden) was closed during night between 1900 and 0600 HR. No assimilation light was used. Greenhouse macroclimate (RH and air temperature) was measured with a commercial climate measuring box $(0.8 \mathrm{~m}$ above the crop) equipped with a capacitive hygrometer and a PT500 thermometer (Senmatic, Søndersø, Denmark). Microclimate was measured in the two crop levels $z_{1}$ and $z_{3}$. In both levels, leaf surface temperature was measured with two IR thermocouples (IRTS-P5; Apogee Instruments, Logan, UT); $\mathrm{RH}$ and temperature close to the leaf surfaces (from 3 to $5 \mathrm{~cm}$ distance) were measured with a capacitive hygrometer and a PT100 thermometer, respectively (Hygroclip S3; Rotronic, Basserdorf, Switzerland). Because $z_{1}$ and $z_{3}$ were a function of the LAI (Eq. [12]), the measuring equipment was adjusted weekly. $P P F$ density $\left(\mathrm{I}_{P P F}, \mu \mathrm{mol} \cdot \mathrm{m}^{-2} \cdot \mathrm{s}^{-1}\right)$ was measured with two line quantum sensors (LI-190SA; LI-COR, Lincoln, Neb.). All data were continuously recorded and logged with 1-min averages in two computer-controlled data loggers (DT 600 with DeLogger 4; DataTaker, Rowville, Australia).

In Expt. 2, temperature was controlled by the IntelliGrow system, a complex control regime (Aaslyng et al., 2003). Expt. 2 compared the microclimate attained with a regular and a dynamic temperature regime. Within the dynamic regime, temperature could fluctuate differently between days; set points were fixed for the regular regime (Table 1). Expt. 2 was a long-term experiment (5 Sept. 2001-27 May 2002) with a total of seven batches of potted roses (Rosa, 'Vanilla Charming Parade') grown sequentially until plants had reached the commercial harvest stage. Young potted roses were placed to a density of 40 plants $\mathrm{m}^{2}$ on ebb and flow tables $\left(7 \mathrm{~m}^{2}\right)$ in four greenhouse compartments $\left(66 \mathrm{~m}^{2}\right.$ each) of the Royal Veterinary and Agricultural University (Copenhagen, Denmark, 55 $41^{\prime} \mathrm{N}$ ).

In Expt. 2, outdoor climate was measured by a standard weather station. Greenhouse macroclimate as air temperature (10K3MCD1; BetaTHERM, Galway, Ireland), $\mathrm{CO}_{2}$ concentration (from 0 to 2000 $\mu \mathrm{mol} \cdot \mathrm{mol}^{-1} \pm 10 \mu \mathrm{mol} \cdot \mathrm{mol}^{-1}$ ) (URAS 4; Hartmann \& Braun, Frankfurt, Germany), air humidity (from $0 \%$ to $100 \% \mathrm{RH}, \pm 1.5 \%$ ) (Hygroclip S; Rotronic, Basserdorf, Switzerland), global radiation (CM-11 pyranometer; Kipp and Zonen, Delft, The Netherlands), and $\mathrm{I}_{P P F}$ (G1125-06; Hammamatsu, Japan; and LI-190SA; LI-COR) were measured and computer-controlled (LCC1200; DGT Volmatic, Odense, Denmark). The climate set points were generated with the IntelliGrow software (Aaslyng et al., 2003) that was implemented in another computer and sent to the LCC1200 in a 10-min time interval (Aaslyng et al., 2005). Set points were determined from macroclimate measurements and either calculated dynamically or by the regular regime (Table 1). Greenhouse microclimate as temperature (four evenly distributed type $\mathrm{T}$ thermocouples and one infrared [IR] thermocouple) (Sensycon; Hartmann \& Braun, Frankfurt, Germany; Exergen IR, Watertown, Mass., respectively), $\mathrm{I}_{P P F}$ (G1125-06; Hammamatsu, Japan; and LI-190SA; LI-COR), and global radiation (CM-3 pyranometer; Kipp and Zonen) were measured on each table on sunlit leaves only (position $\mathrm{z}_{1}$ ). Greenhouse com- partments roof temperatures were measured with thermistors (100K6MCD1; BetaTHERM, Shrewsbury, Mass.) on the north and on the south side of each greenhouse compartment. The same type of thermistors were also used to measure soil temperature and pipe heating in- and outlet temperatures. All data were continuously measured, averaged over $5 \mathrm{~min}$, and stored in a data logger (CR10X; Campbell Scientific, Logan, Utah). Supplementary lighting was used (see Table 1). Ten high-pressure sodium lamps (SON-T, $400 \mathrm{~W}$; Philips, Eindhoven, The Netherlands) were installed in each greenhouse compartment $\left(0.152\right.$ lamps per $\left.\mathrm{m}^{2}\right)$. Next to visible radiation, the high-pressure sodium lamps produced $80 \mathrm{~W}$ IR radiation and $202 \mathrm{~W}$ heat plus an additional $36 \mathrm{~W}$ produced by the generator. For simple estimation of longwave radiation exchange with the upper leaf surface (Eq. [11]), it was assumed that $50 \%$ of the heat production reached the crop top surface.

Simulating greenhouse microclimate. The previously described model was programmed in the simulation software environment MATLAB (version 7.2; The MathWorks; Lowell, Mass.). The model's sensitivity was tested with artificially created climate data (Table 2). Simulations were performed with measured greenhouse macroclimate data (Expts. 1 and 2) using a 5-min simulation time step.

Climate control simulation study. For a simulation study, a greenhouse climate and control simulator (GCCS) (Körner et al., 2004) was connected to the presented microclimate model. The GCCS calculated greenhouse macroclimate for a standard 1-ha Venlo-type greenhouse with a single glass

Table 1. Overview of the set points used in the dynamic climate regime in Expt. 2 (Lund et al., 2006).

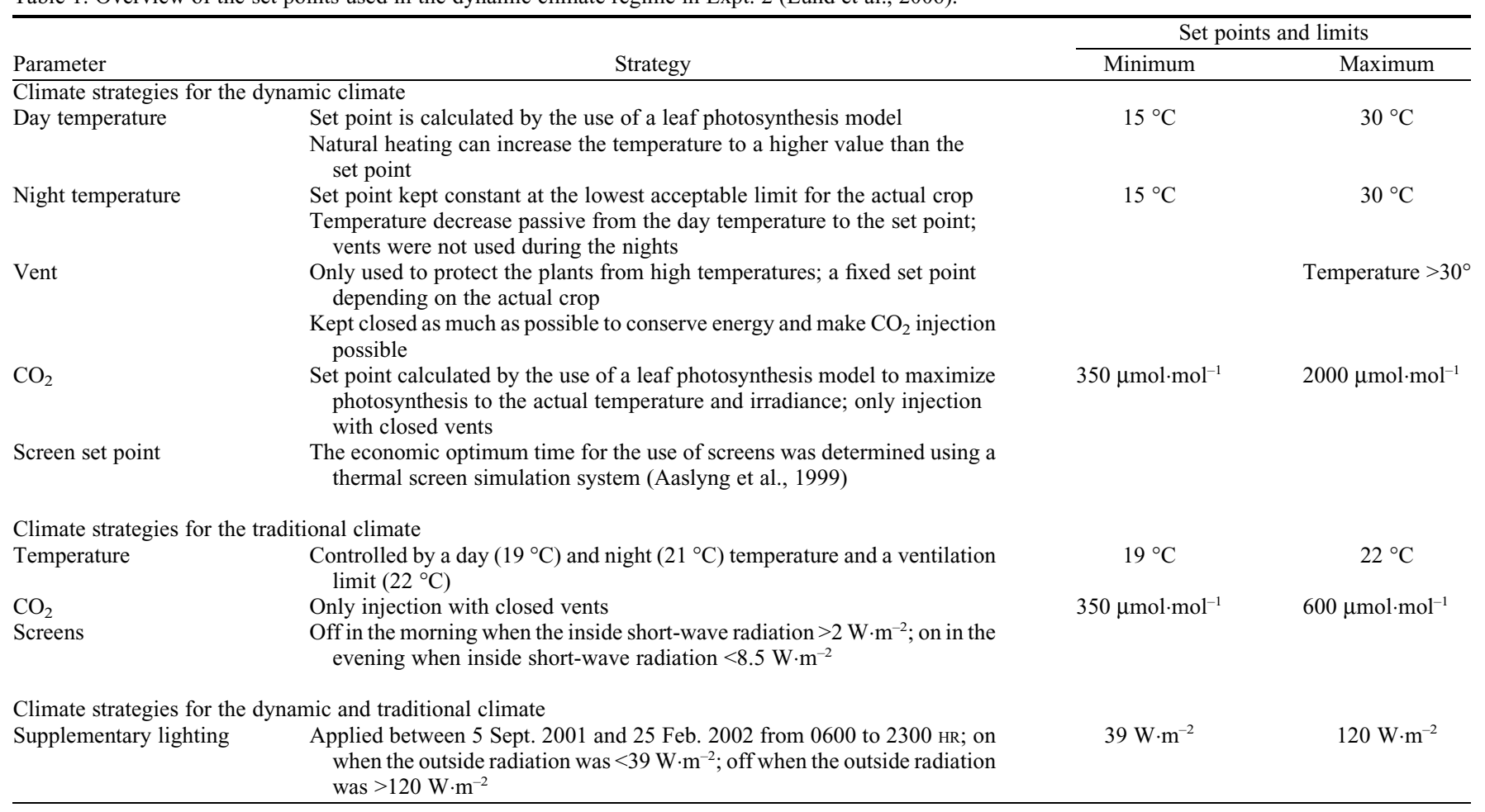


cover (transmission for diffuse radiation of 78.5\%), energy-saving screen (LS10; Ludvig Svensson, Kinna, Sweden), and assimilation light. The Danish 1-year reference climate data file (Design Reference Year [DRY]; Lund, 1995) was input to the GCCS. Control inputs were climate set points for heating, ventilation, $\mathrm{CO}_{2}$ concentration, and screening. Those were generated by a set point generator program (SPG) and provided to the GCCS by data file-sharing in a 5-min interval. This simulation study compared the effect on energy consumption and the microclimate factors dew formation and crop temperature of 1) commonly used greenhouse climate control with greenhouse air temperature with 2) greenhouse climate control with crop temperature, meaning the SPG either used greenhouse air temperature or crop temperature as the basis for set point calculations. Two temperature regimes were tested: 1) regular temperature set points for day and night with a $1{ }^{\circ} \mathrm{C}$ margin between heating and ventilation, and 2) a dynamic 24-h temperature integration regime in which temperature could fluctuate freely between the calculated heating and ventilation temperatures (Table 3). Both regimes were thoroughly described in Körner et al. (2004).

\section{Results}

Model presentation. The model predicted a strong dependency of crop temperature to short-wave radiation and greenhouse air temperature. The effect of short-wave radiation decreased with increasing LAI (i.e., the effect on $\mathrm{z}_{1}$ leaves was higher than on $\mathrm{z}_{2}$ or $\mathrm{z}_{3}$ leaves) and decreased with increasing greenhouse air temperature (Figs. 1 and 2). The difference between crop temperature and cover temperature increased with an increasing gradient between inside and outside greenhouse temperature. In this situation, leaves exchange less long-wave radiation if they are situated in lower canopy levels and therefore lose less energy than leaves in higher levels. This leads to temperature difference between $z_{1}$ and $z_{3}$ leaves. Increasing the short-wave radiation had the opposite effect (Figs. 1 and 2). Strong effects of shortwave radiation on potential evaporation could be observed, too. When short-wave radiation was high, $\lambda \mathrm{E}$ decreased with increasing LAI (Fig. 3). At darkness, $\lambda \mathrm{E}$ reacted opposite to that, and when $\mathrm{RH}$ was very high, negative $\lambda \mathrm{E}$ values could be observed in $z_{1}$ leaves, i.e., condensation on the plant surface and an increasing risk of diseases (Fig. 3). The effects of short-wave radiation on both leaf temperature and dew formation (i.e., negative $\lambda \mathrm{E}$ ) decreased with increasing LAI (Figs. 3 and 4). Those effects were strongest when short-wave radiation was high, because the position of $\mathrm{z}$ in the canopy was not constant but defined by LAI (Eq. [1]).

Greenhouse experiments. The model was able to predict leaf surface temperature well for both $z_{1}$ and $z_{3}$ leaves when temperature fluctuations were preprogrammed (Expt. 1)

Table 2. Simulations settings for climate control study with simulation range (range) and simulation time steps (step unit).

\begin{tabular}{lcccc}
\hline & $\begin{array}{c}\text { Greenhouse air } \\
\text { temperature }\left({ }^{\circ} \mathrm{C}\right)\end{array}$ & $\begin{array}{c}\text { Relative } \\
\text { humidity }(\%)\end{array}$ & $\begin{array}{c}\text { Global radiation } \\
\left(\mathrm{W} \cdot \mathrm{m}^{-2}\right)\end{array}$ & $\begin{array}{c}\text { Leaf area } \\
\text { index }\left(\mathrm{m}^{2} \cdot \mathrm{m}^{-2}\right)\end{array}$ \\
\hline Range & $0-40$ & $50-100$ & $0-200$ & $0-4$ \\
Step unit & 1 & 10 & 20 & 0.1 \\
\hline
\end{tabular}

Table 3. Climate settings for simulation study for regular and dynamic (24-h temperature integration) climate control: ventilation temperature $\left(\mathrm{T}_{\mathrm{v}}\right)$, heating temperature $\left(\mathrm{T}_{\mathrm{h}}\right)$, relative humidity $(\mathrm{RH}), \mathrm{CO}_{2}$ concentration.

\begin{tabular}{lcc}
\hline & Regular & Dynamic \\
\hline $\mathrm{T}_{\mathrm{v}}\left({ }^{\circ} \mathrm{C}\right)$ & 19 & Dynamic, maximum 23.0 \\
$\mathrm{~T}_{\mathrm{h}}\left({ }^{\circ} \mathrm{C}\right)$ & 18 & Dynamic, minimum 15.5 \\
$\mathrm{RH}(\%)$ & 85 & 85
\end{tabular}

$\mathrm{CO}_{2}\left(\mu \mathrm{mol} \cdot \mathrm{mol}^{-1}\right)$

Screen (off-on)

Assimilation light $\left(\mathrm{W} \cdot \mathrm{m}^{-2}\right)$

Leaf area index
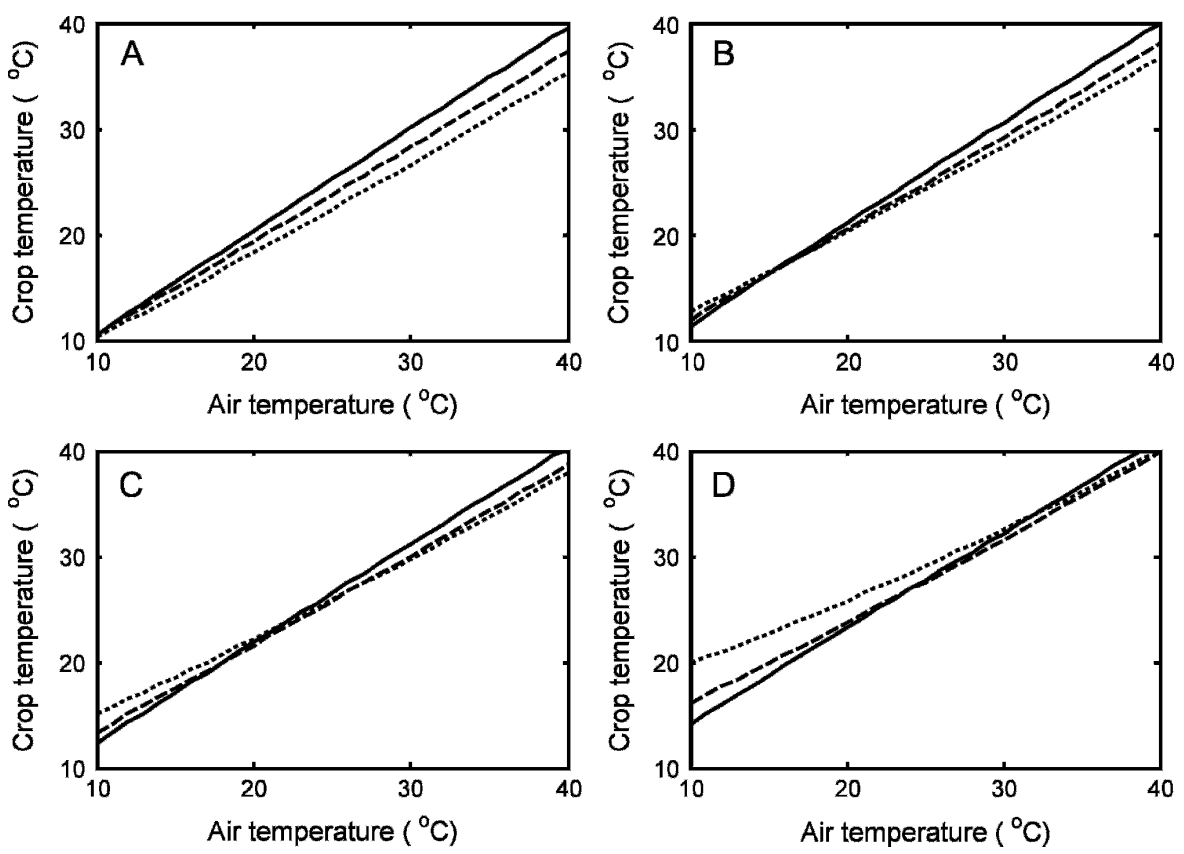

Fig. 1. Simulated crop temperature in three canopy positions $\left(\mathrm{z}_{1}[-], \mathrm{z}_{2}[--]\right.$, and $\left.\mathrm{z}_{3}[-]\right)$ as a function of greenhouse air temperature for four inside global radiation levels: (A) $0 \mathrm{~W} \cdot \mathrm{m}^{-2},(\mathbf{B}) 40 \mathrm{~W} \cdot \mathrm{m}^{-2}$, (C) $80 \mathrm{~W} \cdot \mathrm{m}^{-2}$, and (D) $160 \mathrm{~W} \cdot \mathrm{m}^{-2}$. All other factors were set constant: leaf area index 2, relative humidity $80 \%$, outside air temperature $15{ }^{\circ} \mathrm{C}, \mathrm{CO}_{2} 350 \mu \mathrm{mol} \cdot \mathrm{mol}^{-1}$ (see Table 2 ).
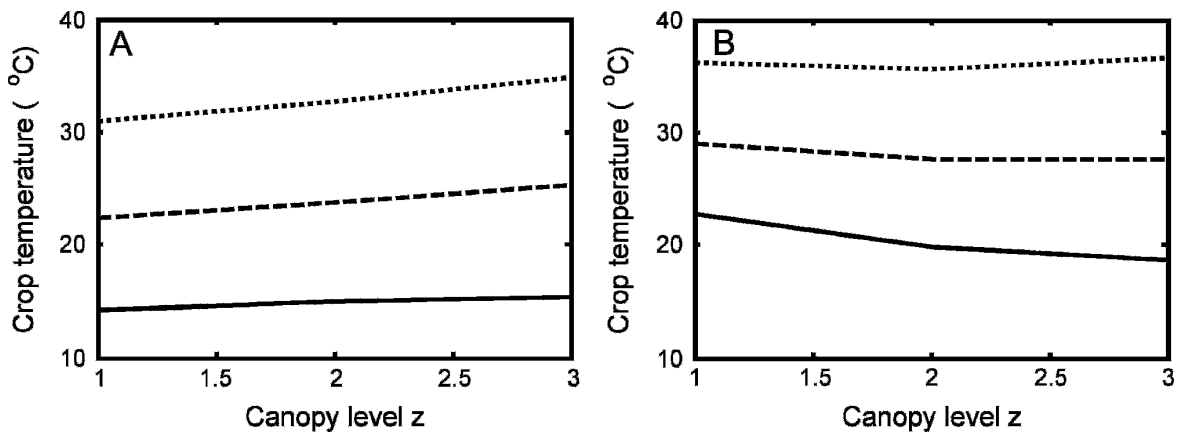

Fig. 2. Simulated crop temperature at $15^{\circ} \mathrm{C}(-), 25^{\circ} \mathrm{C}(--)$, and $35^{\circ} \mathrm{C}(-)$ air temperature as a function of the canopy level $\mathrm{z}$ at (A) $0 \mathrm{~W} \cdot \mathrm{m}^{-2}$ or (B) $160 \mathrm{~W} \cdot \mathrm{m}^{-2}$ global radiation inside the greenhouse. All other factors were set constant: LAI 1.5 , RH $80 \%$, outside air temperature $15^{\circ} \mathrm{C}, \mathrm{CO}_{2} 350 \mu \mathrm{mol} \cdot \mathrm{mol}^{-1}$ (see Table 2). 

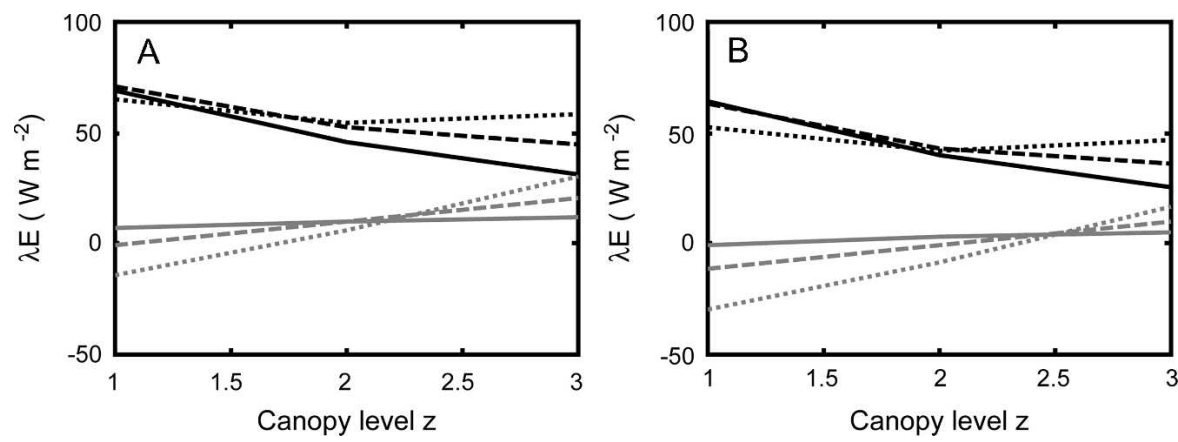

Fig. 3. Simulated latent heat of evaporation at $15^{\circ} \mathrm{C}(-), 25^{\circ} \mathrm{C}(--)$, and $35^{\circ} \mathrm{C}(-)$ air temperature as a function of the canopy level $\mathrm{z}$ at $0 \mathrm{~W} \cdot \mathrm{m}^{-2}$ (gray lines) or $160 \mathrm{~W} \cdot \mathrm{m}^{-2}$ (black lines) global radiation inside the greenhouse at (A) $70 \%$ or (B) $100 \%$ relative humidity. All other factors were set constant: leaf area index 1.5 , outside air temperature $15^{\circ} \mathrm{C}, \mathrm{CO}_{2} 350 \mu \mathrm{mol} \cdot \mathrm{mol}^{-1}$ (see Table 2).
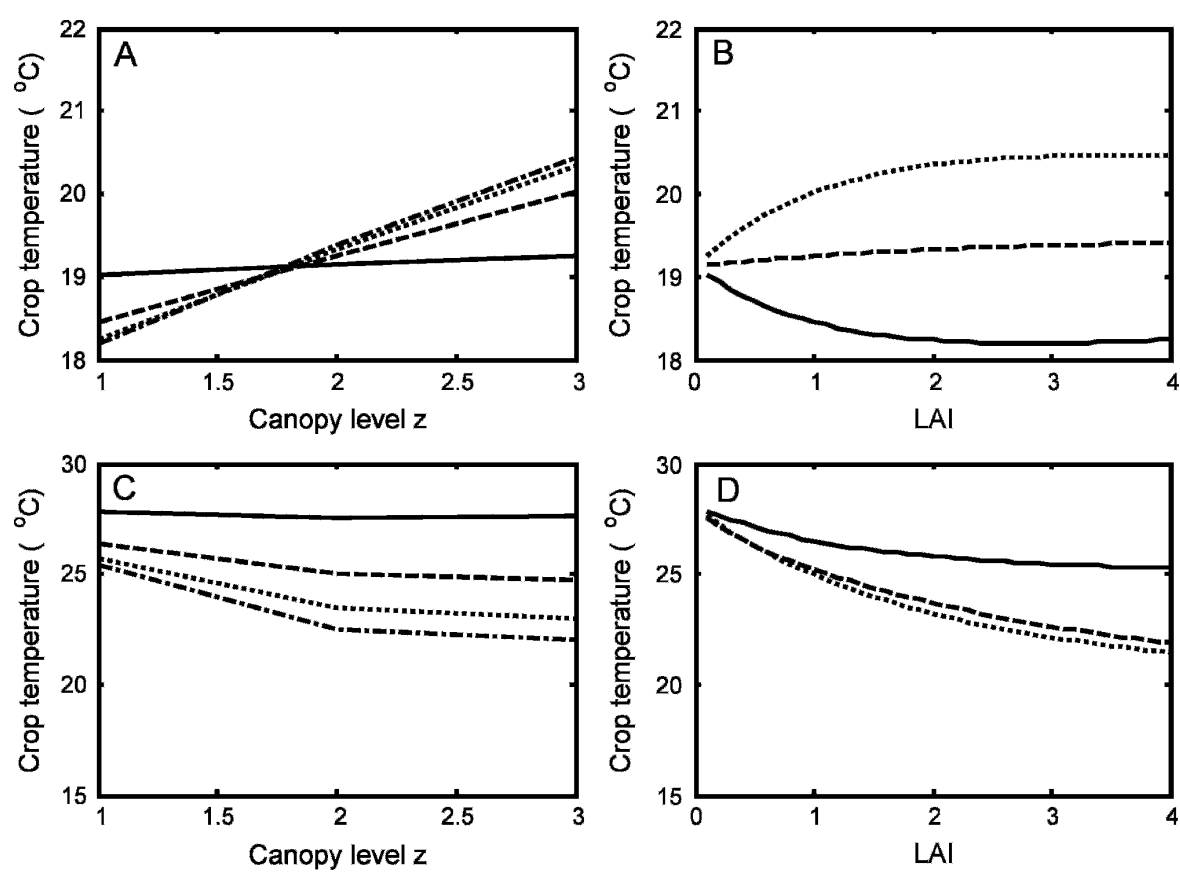

Fig. 4. Crop temperature at different inside greenhouse global radiation levels of $(\mathbf{A}, \mathbf{B}) 0 \mathrm{~W} \cdot \mathrm{m}^{-2}$ and (C, D) $160 \mathrm{~W} \cdot \mathrm{m}^{-2}$ as a function of the canopy level $\mathrm{z}$ and at $(\mathbf{A}, \mathbf{C})$ four different leaf area indexes (LAI 0.1 [-], LAI 1 [--], LAI 2 [-], LAI 3 [-- - ]) and (B, D) three different canopy levels $\left(\mathrm{z}_{1}\right.$ [-], $\mathrm{z}_{2}[-]$, and $\left.\mathrm{z}_{3}[--]\right)$. All other factors were set constant: greenhouse air temperature $20^{\circ} \mathrm{C}$, relative humidity $80 \%$, outside air temperature $15^{\circ} \mathrm{C}, \mathrm{CO}_{2} 350 \mu \mathrm{mol} \cdot \mathrm{mol}^{-1}$ (see Table 2) LAI indicates leaf area index.

(Fig. 5). However, periodically, some incongruence occurred. The natural heating up and cooling down of the greenhouse (no heating) was well predicted (high and low peaks). Only when pipe heating was used to heat up the greenhouse after a cool period did the model disagree with the measurements. However, the difference in predicted and measured temperature was noteworthy only during these periods.

In situations when the greenhouse climate was more actively controlled than in Expt. 1, i.e., also with artificial lighting, screens, and vents (Expt. 2), the model had to be adjusted to these circumstances. When energy exchanges with the lamps when greenhouse climate was controlled to crop temperature (rather than to greenhouse air temperature) (Table 4). Because results with the regular climate regime were similar to the dynamic regime, no further data are presented. Greenhouse air temperature control resulted in warmer plants than wanted throughout the year. The difference in crop temperature between air and crop temperature control was most eminent in winter. In January, leaf temperature in all three vertical crop levels was $\approx 1{ }^{\circ} \mathrm{C}$ higher with greenhouse air temperature control than with crop temperature control. For that, unnecessary heating energy was used (Table 4). Shifting from greenhouse air temperature control to crop temperature control with the presented model could save more than $12 \%$ energy in January. Energy-saving percentages decreased toward summer. Only a small positive effect of crop temperature control on dew formation could be observed (Table 4).

\section{Discussion}

Microclimate prediction models applicable for model-based greenhouse climate control are scarce. We therefore aimed at creating a simple microclimate model with the prediction quality demanded in dynamic greenhouse climate control. Quality assessment of a crop microclimate model quality includes mainly five major points: 1) general fit between real and simulated crop temperature, 2) prediction quality of high and low temperature peaks, 3) predicting the difference in temperature fluctuation speed between air and plants, 4) predicting the vertical microclimate differences in the crop canopy, and 5) prediction of the horizontal microclimate differences in the greenhouse.

The general fit between simulated and measured crop temperature was satisfying. However, the model yielded in some biased predictions of leaf temperature, with the largest over- and underestimations during warming up of the greenhouses through pipe heating. Estimating leaf temperature was however successful when temperature was not controlled. The discrepancies between measured and simulated leaf temperatures in some periods can probably be explained by the complexity of the greenhouses the measurements were taken in. In addition, microclimate predictions with the complete dynamic regime and with more active climate control and assimilation light (Expt. 2) had a lower quality. This could probably be explained through strong simplifications in the model construction for, e.g., artificial assimilation light or heating pipes. Also, greenhouse size, position of the heating pipes, table structures and positions, and table distances from heating pipes, and so on, differ between greenhouses and the greenhouse equipment, which was only approximated and roughly implemented in the model. Because greenhouses in northern 

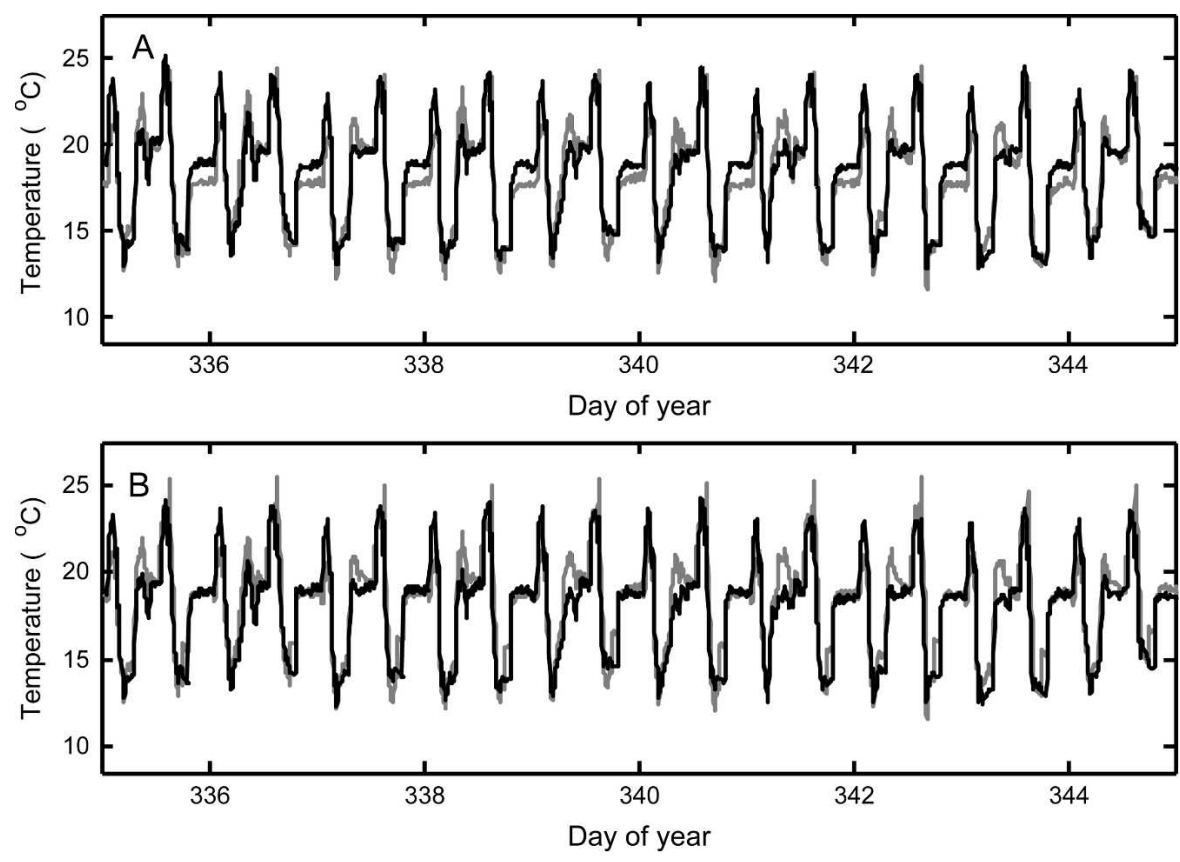

Fig. 5. Measured (black) and simulated (gray) crop temperature for $(\mathbf{A}) \mathrm{z}_{3}$ leaves and $(\mathbf{B}) \mathrm{z}_{1}$ leaves during $10 \mathrm{~d}$ of Expt. 1 (day 335 to day 344 of the year). The position of the indicated day numbers is at $1800 \mathrm{HR}$.
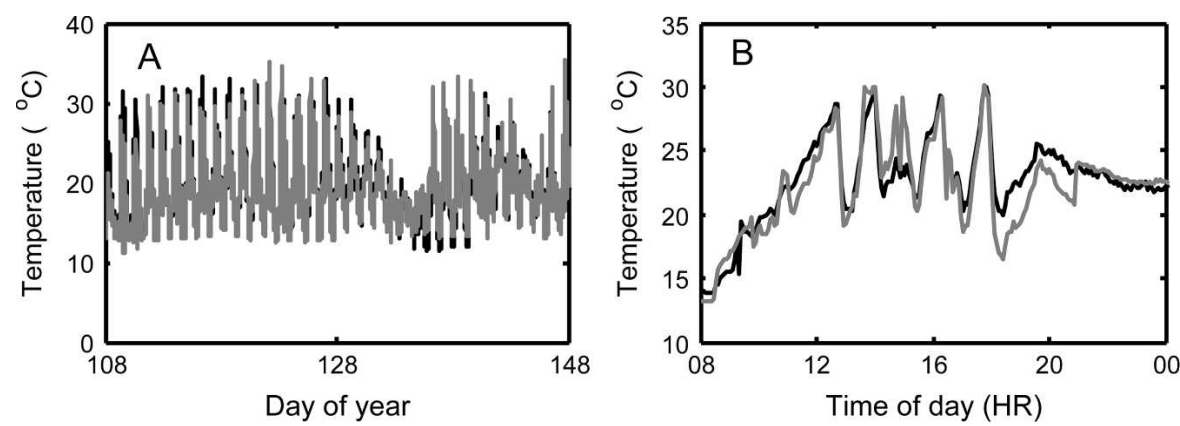

Fig. 6. Measured (black) and simulated (gray) pot-rose crop temperature with data from Expt. 2 for $40 \mathrm{~d}$ (A) (between day of the year 108 and 148) and day of year 147 (B) for a dynamic climate regime with the IntelliGrow system.

Europe are often equipped with assimilation lights, a better implementation of those (and other equipment) will strongly improve the quality of the model and its potential for the use in practice. There are many parameters that could improve the models prediction quality, e.g., heat transfer calculations between heating pipes and tables, tables and pots, and plants and side walls. Other parameters such as the influence of water on the tables on crop microclimate, the thickness of leaves, or the compactness of the plants was not taken into account either. Furthermore, assuming that the sum of all nonliving greenhouse material temperatures $\left(\mathrm{T}_{\mathrm{g}}\right)$ is the same as greenhouse air temperature may not be correct, but to include the complete interior of the greenhouse involves complex calculations and model adjustments. Different materials can either be warmer or colder than the air (depending on greenhouse climate, material, and humidity content). Because we
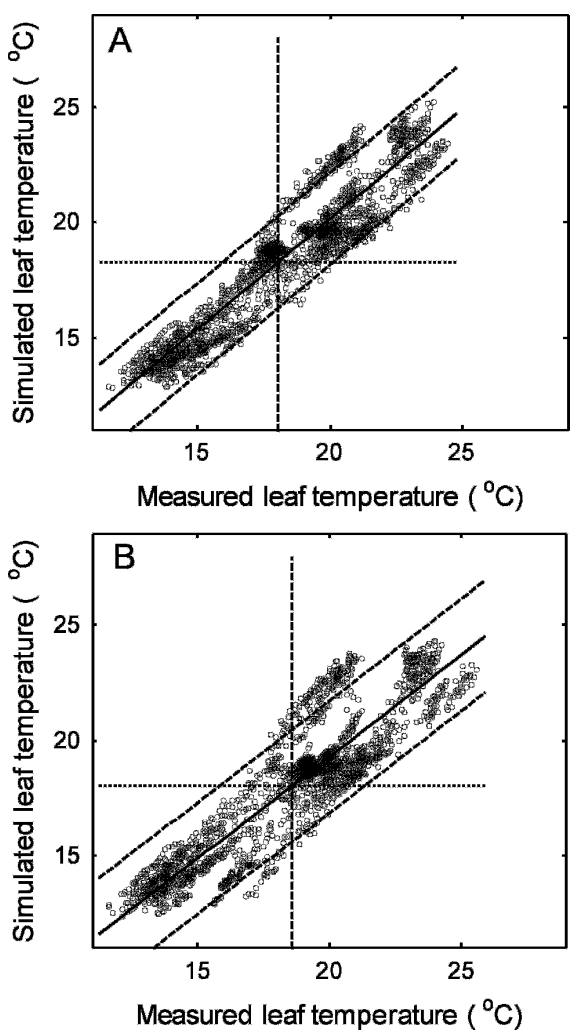

Fig. 7. Simulated versus measured leaf temperature for (A) $z_{1}$ leaves and (B) $z_{3}$ leaves in Expt. 1 with $95 \%$ nonsimultaneous confidence intervals: (A) $\pm 1.99{ }^{\circ} \mathrm{C}$ and (B) $\pm 2.43{ }^{\circ} \mathrm{C}$.

facilities that are very different from commercial-sized greenhouses that can measure several hectares. The climate in large greenhouses is probably more uniform and a general model, like the one presented here, could probably be applied much easier under such conditions. The present model was demonstrated through sensitivity analysis and through model validation with data from two different research greenhouses. Although the accuracy of the predictions differed in the two greenhouse experiments, these differences were small.

The presented microclimate model has the potential for being generic. A simulation case study showed that using this model to predict crop microclimate is a promising alternative to greenhouse air temperature control and may be used for model-based dynamic control regimes (Aaslyng et al., 1999; Bailey, 1985; Bailey and Seginer, 1989; Buwalda et al., 1999; Körner and Challa, 2003a; Seginer et al., 1994) or for the concept of optimal greenhouse climate control (Gal et al., 1984). Because $10 \%$ energy is saved by a $1{ }^{\circ} \mathrm{C}$ lower greenhouse temperature (Tantau, 1998), heating demand and therefore energy consumption can strongly decrease when using this microclimate model for crop temperature control. This was also shown in the simulation study. Controlling the greenhouse climate more specific to the coldest crop layer (rather than using an average crop temperature as the control) 

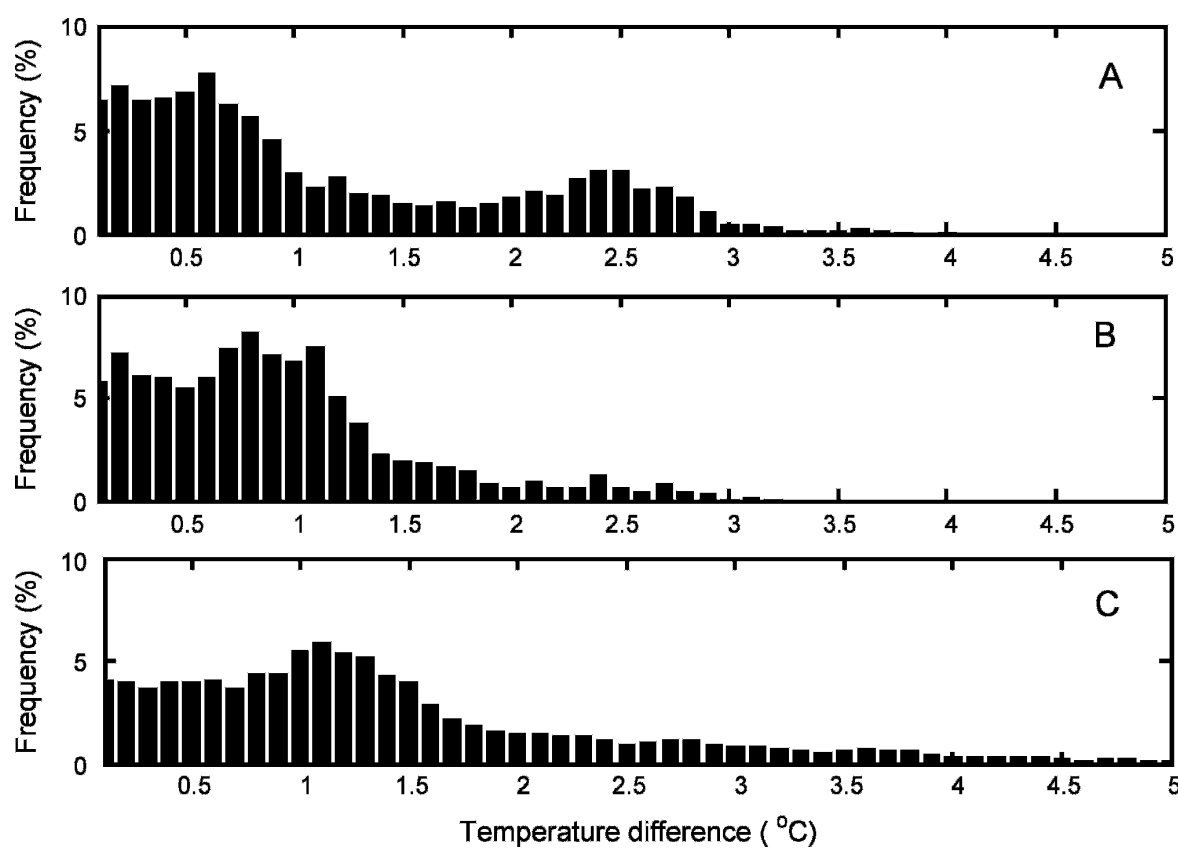

Fig. 8. Frequency diagrams of absolute deviations from simulated to measured leaf temperature in Expt. 1 for $(\mathbf{A}) z_{1}$ and (B) $z_{3}$ and (C) Expt. 2 .

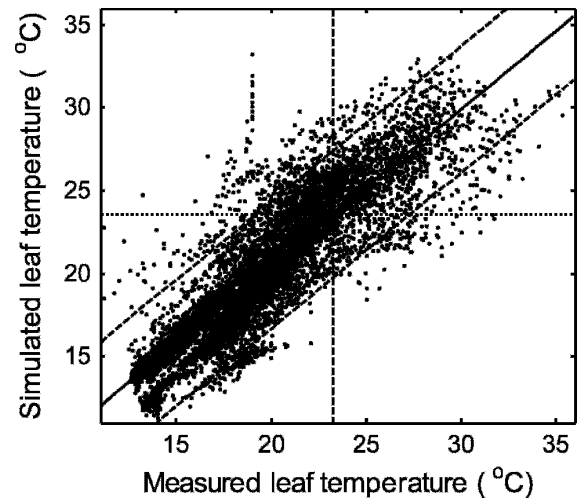

Fig. 9. Simulated versus measured leaf temperature for $\mathrm{z}_{1}$ leaves during $40 \mathrm{~d}$ in Expt. 2 with the $95 \%$ nonsimultaneous confidence interval $\left( \pm 3.8^{\circ} \mathrm{C}\right)$

Table 4. Weekly averages of air temperature, crop temperature, and sums for dew; and energy consumption in three canopy levels $\mathrm{z}$ for simulations with dynamic climate control (see Table 3 ) with air temperature or crop temperature control (ATC or LTC) and standard deviation. ${ }^{2}$

\begin{tabular}{|c|c|c|c|c|c|c|c|c|c|}
\hline \multirow[b]{3}{*}{ Week } & \multirow{3}{*}{$\begin{array}{c}\text { Canopy } \\
\text { level }\end{array}$} & \multicolumn{8}{|c|}{ Variable } \\
\hline & & \multicolumn{2}{|c|}{$\begin{array}{c}\text { Air temperature } \\
\left({ }^{\circ} \mathrm{C}, \text { mean }\right)\end{array}$} & \multicolumn{2}{|c|}{$\begin{array}{c}\text { Crop temperature } \\
\left({ }^{\circ} \mathrm{C}, \text { mean }\right)\end{array}$} & \multicolumn{2}{|c|}{$\begin{array}{l}\text { Sums for dew } \\
\text { (minutes) }\end{array}$} & \multicolumn{2}{|c|}{$\begin{array}{l}\text { Energy consumption } \\
\left(\text { total sum, } \mathrm{MJ} \cdot \mathrm{m}^{-2} \text { ) }\right.\end{array}$} \\
\hline & & ATC & LTC & ATC & LTC & ATC & LTC & ATC & LTC \\
\hline \multirow[t]{3}{*}{1} & $\mathrm{z}_{1}$ & $18.1 \pm 2.7$ & $16.9 \pm 1.7$ & $18.9 \pm 3.1$ & $17.9 \pm 2.5$ & 180 & 180 & 49 & 43 \\
\hline & $z_{2}$ & & & $19.2 \pm 2.9$ & $18.1 \pm 2.1$ & 45 & 40 & & \\
\hline & $z_{3}$ & & & $19.6 \pm 2.6$ & $18.5 \pm 1.7$ & 0 & 0 & & \\
\hline \multirow[t]{3}{*}{5} & $z_{1}$ & $18.0 \pm 2.9$ & $16.9 \pm 1.7$ & $19.3 \pm 3.1$ & $18.3 \pm 2.5$ & 130 & 125 & 43 & 39 \\
\hline & $z_{2}$ & & & $19.4 \pm 3.0$ & $18.3 \pm 2.0$ & 50 & 45 & & \\
\hline & $\mathrm{z}_{3}$ & & & $19.7 \pm 2.8$ & $18.6 \pm 1.7$ & 0 & 0 & & \\
\hline \multirow[t]{3}{*}{9} & $\mathrm{z}_{1}$ & $18.1 \pm 2.9$ & $17.2 \pm 2.3$ & $20.6 \pm 4.2$ & $19.8 \pm 4.2$ & 90 & 85 & 35 & 32 \\
\hline & $z_{2}$ & & & $20.1 \pm 3.3$ & $19.3 \pm 3.1$ & 20 & 10 & & \\
\hline & $z_{3}$ & & & $20.2 \pm 3.1$ & $19.4 \pm 2.7$ & 0 & 0 & & \\
\hline \multirow[t]{3}{*}{13} & $\mathrm{z}_{1}$ & $18.4 \pm 3.2$ & $17.9 \pm 2.9$ & $20.8 \pm 5.2$ & $20.4 \pm 5.2$ & 100 & 100 & 25 & 24 \\
\hline & $\mathrm{z}_{2}$ & & & $20.1 \pm 4.0$ & $19.7 \pm 3.9$ & 20 & 35 & & \\
\hline & $z_{3}$ & & & $20.2 \pm 3.6$ & $19.8 \pm 3.5$ & 0 & 0 & & \\
\hline
\end{tabular}

${ }^{\mathrm{z}}$ The target temperature range was from 18 to $19{ }^{\circ} \mathrm{C}$.

${ }^{\mathrm{y}}$ Dew was attained when the latent heat of evaporation $\left(\lambda \mathrm{E}, \mathrm{W} \cdot \mathrm{m}^{-2}\right.$, Eq. [3]) was negative.

\section{Literature Cited}

Aaslyng, J.M., N. Ehler, and L. Jakobsen. 2005. Climate control software integration with a greenhouse environmental control computer. Environ. Model. Softw. 20:521-527.

Aaslyng, J.M., N. Ehler, P. Karlsen, and E. Rosenqvist. 1999. Intelligrow: A component based greenhouse climate control system for decreasing energy consumption. Acta Hort. 507:35-41.

Aaslyng, J.M., O. Körner, A.U. Andreassen, J.B. Lund, J. Skov, C.O. Ottosen, and E. Rosenqvist. 2006. Integrated optimization of temperature, $\mathrm{CO} 2$, screen and artificial lighting in greenhouse crops. Acta Hort. 711:79-88.

Aaslyng, J.M., J.B. Lund, N. Ehler, and E. Rosenqvist. 2003. Intelligrow: A greenhouse component-based climate system. Environ. Model. Softw. 18:657-666.

Bailey, B.J. 1985. Wind dependent control of greenhouse temperature. Acta Hort. 174:381386.

Bailey, B.J. and I. Seginer. 1989. Optimum control of greenhouse heating. Acta Hort. 245:512518.

Ball, J.T., I.E. Woodrow, and J.A. Berry. 1987. A model predicting stomatal conductance and its contribution to the control of photosynthesis under different environmental conditions, p. 221-224. In: J. Biggins (ed.). Progress in photosynthesis research. Martinus Nijhoff, Dordrecht, The Netherlands.

Boonen, C., O. Joniaux, K. Janssen, D. Berckmans, R. Lemeur, A. Kharoubi, and H. Pien. 2000. Modeling dynamic behaviour of leaf temperature at three-dimensional positions to step variation in air temperature and light. Trans. ASAE 43:1755-1766.

Bot, G.P.A. and N.J. Van de Braak. 1995. Radiation, p. 132-134. In: J.C. Bakker, G.P.A. Bot, H. Challa, and N.J. Van de Braak (eds.). Greenhouse climate control, an integrated approach. Wageningen Pers, Wageningen, The Netherlands.

Buwalda, F., A.A. Rijsdijk, J.V.M. Vogelezang, A. Hattendorf, and L.G.G. Batta. 1999. An energy efficient heating strategy for cut rose production based on crop tolerance to temperature fluctuations. Acta Hort. 507:117-125.

De Zwart, H.F. 1996. Analyzing energy-saving options in greenhouse cultivation using a simulation model. Wageningen Agr. Univ., Wageningen, The Netherlands, PhD Diss.

Farquhar, G.D. and S. Von Caemmerer. 1982. Modelling of photosynthetic response to environmental conditions, p. 549-587. In: O.L. Lange, P.S. Nobel, C.B. Osmond, and H. Ziegler (eds.). Water relations and carbon assimilation. Encyclopedia of plant physiology. New-series. Physiol. Plant Ecol. II. Springer-Verlag, Berlin, Germany.

Farquhar, G.D., S. Von Caemmerer, and J.A. Berry. 1980. A biochemical model of photosynthetic $\mathrm{CO}_{2}$ assimilation in leaves of $\mathrm{C} 3$ species. Planta 149:78-90.

Gal, S., A. Angel, and I. Seginer. 1984. Optimal control of greenhouse climate: Methodology. Eur. J. Oper. Res. 17:45-56.

Gijzen, H. 1994. Ontwikkeling van een simulatiemodel voor transpiratie en wateropname en van een integral gewasmodel (in Dutch; Development of a simulation model for transpiration and water uptake and an integral crop model). DLO Rapport 18, AB-DLO, Wageningen, The Netherlands.

Goudriaan, J. and H.H. Van Laar. 1994. Modelling potential crop growth processes. Kluwer, Dordrecht, The Netherlands. 
Huber, L. and T.J. Gillespie. 1992. Modeling leaf wetness in relation to plant disease epidemiology. Annu. Rev. Plant Phytopathol. 30: 553-577.

Jakobsen, L., M. Brogaard, O. Körner, A. Enkegaard, and J.M. Aaslyng. 2005. The influence of a dynamic climate on pests, diseases and beneficial organisms: Recent research, p. 127134. In: A. Enkegaard (ed.). Integrated control in protected crops, temperate climate. IOBC wprs Bulletin, Turku, Finland.

Jones, H.G. 1992. Plants and microclimate. Cambridge University Press, Cambridge, U.K.

Kempkes, F.L.K. and N.J. Van de Braak. 2000. Heating system position and vertical microclimate distribution in chrysanthemum greenhouse. Agr. For. Meteorol. 104:133-142.

Kim, S.H. and J.H. Lieth. 2003. Parameterization and testing of a coupled model of photosynthesis conductance for greenhouse rose crop. Acta Hort. 593:113-120.

Körner, O. 2004. Evaluation of crop photosynthesis models for dynamic climate control. Acta Hort. 654:295-302.

Körner, O., A.U. Andreassen, and J.M. Aaslyng. 2006. Dynamic control of artificial lighting. Acta Hort. 711:151-156.

Körner, O., M.J. Bakker, and E. Heuvelink. 2004. Daily temperature integration: A simulation study to quantify energy consumption. Biosystems Eng. 87:333-343.

Körner, O. and H. Challa. 2003a. Design for an improved temperature integration concept in greenhouse cultivation. Computers Electronics Agr. 39:39-59.

Körner, O. and H. Challa. 2003b. Process-based humidity control regime for greenhouse crops. Computers Electronics Agr. 39:173-192.

Körner, O. and N. Holst. 2005. Model-based humidity control of grey-mould in greenhouse cultivation. Acta Hort. 691:141-148.

Lund, H. 1995. The design reference year user manual, a report of Task 9: Solar radiation and pyranometer studies. Solar Materials Research and Development, International Energy Agency Solar Heating and Cooling Programme, Report No. IEA-SHCP-9E-1, Report No. 274, Thermal Insulation Laboratory, Technical University of Denmark, Denmark.

Lund, J.B., A.U. Andreassen, C.O. Ottosen, and J.M. Aaslyng. 2006. Effect of a dynamic climate on energy consumption and production of Hibiscus rosa sinensis L. in greenhouses. HortScience 41:384-388.

Ross, J. 1975. Radiative transfer in plant communities, p. 13-56. In: J.L. Monteith (ed.). Vegetation and the atmosphere. Academic Press, London, New York, San Francisco.

Seginer, I., C. Gary, and M. Tchamitchian. 1994. Optimal temperature regimes for a greenhouse crop with a carbohydrate pool: A modelling study. Scientia Hort. 60:55-80.

Stanghellini, C. 1987. Transpiration of greenhouse crops. Wageningen Agr. Univ., Wageningen, The Netherlands, PhD Diss.
Tantau, H.J. 1998. Energy saving potential of greenhouse climate control. Math. Comput. Simul. 48:93-101.

Thornley, J.H.M. 1976. Mathematical models in plant physiology. Academic Press, London, U.K.

Van Kraalingen, D.W.G. and C. Rappoldt. 1989. Subprograms in simulation models. CABO Report 18, CABO, Wageningen, The Netherlands.

Van Pee, M., K. Janssen, D. Berckmans, and R. Lemeur. 1998. Dynamic measurement and modelling of climate gradients around a plant for micro environmental control. Acta Hort. 456:399-406.

Wang, S. and J. Deltour. 1999. An experimental model for leaf temperature of greenhousegrown tomato. Acta Hort. 491:101-106.

Yang, X. 1995. Greenhouse micrometeorology and estimation of heat and water vapour fluxes. J. Agr. Eng. Res. 61:227-238.

Yu, Q., J. Goudriaan, and T.D. Wang. 2001. Modelling diurnal courses of photosynthesis and transpiration of leaves on the basis of stomatal and non-stomatal responses, including photoinhibition. Photosynthetica 39:43-51.

Zhang, Y., T.J. Jewett, and J.L. Shipp. 2002. A dynamic model to estimate in-canopy and leafsurface microclimate of greenhouse cucumber crops. Trans. ASAE 45:179-192.

Zhang, Y., Y. Mahrer, and M. Margolin. 1997. Predicting the microclimate inside a greenhouse: An application of a one-dimensional numerical model in an unheated greenhouse. Agr. For. Meteorol. 86:291-297.

\section{Notation}

\begin{tabular}{|c|c|c|c|}
\hline & & $\mathrm{P}_{\mathrm{nl}}$ & Leaf net assimilation rate \\
\hline $\mathrm{a}$ & Leaf absorbance of short-wave radiation & $\mathrm{P}_{\mathrm{nl}, \max }$ & Maximum leaf net photosynthesis \\
\hline$\alpha_{l}$ & Leaf photochemical efficiency & $\lambda$ & Psychrometric constant \\
\hline$\beta$ & Coefficient of thermal expansion & Q & Incoming solar short-wave radiation to the crop \\
\hline $\mathrm{C}_{1}$ & $\mathrm{CO}_{2}$ partial pressure at the leaf surface & $\mathrm{RH}_{1}$ & Relative humidity at leaf surface \\
\hline$c_{p}$ & Specific heat capacity of the air & $\mathrm{RH}$ & Relative humidity of air \\
\hline$\delta$ & Slope between saturated vapor pressure and air temperature & $\mathrm{r}_{\mathrm{b}}$ & Boundary layer resistance \\
\hline$\varepsilon_{\mathrm{c} 0}$ & Emissivity of crop surface & $\mathrm{r}_{\mathrm{s}}$ & Stomata resistance \\
\hline$\varepsilon_{r}$ & Emissivity of greenhouse cover or screen & $\mathrm{r}_{\mathrm{s}, \min }$ & Minimum stomata resistance \\
\hline$\varepsilon_{g}$ & Emissivity greenhouse surfaces & $\mathrm{R}_{\mathrm{n}, \mathrm{a}}$ & Absorbed irradiative net fluxes \\
\hline$\varepsilon_{\mathrm{c} 0, \mathrm{r}}$ & Effective emissivities between crop and cover or screen & $\operatorname{Re}$ & Reynolds number \\
\hline$\varepsilon_{\mathrm{c} 0, \mathrm{~g}}$ & Effective emissivities between crop and greenhouse surfaces & $\rho_{a}$ & Air density \\
\hline $\mathrm{E}_{\mathrm{AL}}$ & Heat energy and long-wave radiation produced by the lamps & SPG & Set point generator program \\
\hline g & Acceleration resulting from gravity & $\sigma$ & Stefan-Boltzmann constant \\
\hline GCCS & Greenhouse climate and control simulator & $\mathrm{T}_{\mathrm{a}}$ & Air temperature \\
\hline $\mathrm{Gr}$ & Grashof number & $\mathrm{T}_{\mathrm{c}}$ & Crop temperature \\
\hline $\mathrm{I}_{\mathrm{PPF}}$ & Photosynthetic photon flux density & $\mathrm{T}_{\mathrm{g}}$ & Greenhouse surface temperatures \\
\hline $\mathrm{k}$ & Conversion factor from $\left[\mathrm{m}^{2} \cdot \mathrm{s} \cdot \mathrm{mol}^{-1}\right]$ to $\left[\mathrm{s} \cdot \mathrm{m}^{-1}\right]$ & $\mathrm{T}_{\mathrm{r}}$ & Greenhouse cover or screen temperature \\
\hline 1 & Characteristic dimension of the leaf surface & $\mathrm{T}_{\mathrm{c} 0}$ & Crop temperature at crop level leaf area index of 0 \\
\hline $\mathrm{L}_{\mathrm{d}}$ & Long wave radiation exchanges at the lower leaf surfaces & $\tau_{\mathrm{d}}$ & Penetration functions for downward long-wave radiation \\
\hline $\mathrm{L}_{\mathrm{n}}$ & $\begin{array}{l}\text { Long-wave radiation exchange between the leaves and the } \\
\text { greenhouse }\end{array}$ & $\tau_{\mathrm{u}}$ & Penetration functions for upward long-wave radiation \\
\hline $\mathrm{L}_{\mathrm{u}}$ & Long-wave radiation exchanges at the upper leaf surfaces & $\theta$ & Atmospheric pressure \\
\hline $\mathrm{L}_{\mathrm{d}}(0)$ & $\begin{array}{l}\text { Radiation exchanges from lower leaf surfaces at a crop level leaf } \\
\text { area index of } 0\end{array}$ & $\mathrm{u}$ & Air velocity \\
\hline $\mathrm{L}_{\mathrm{u}}(0)$ & $\begin{array}{l}\text { Radiation exchanges from upper leaf surfaces at a crop level leaf } \\
\text { area index of } 0\end{array}$ & $\mathrm{VPD}_{\mathrm{s}}$ & Vapor pressure deficit at the leaf surface \\
\hline LAI & Leaf area index & v & Kinematic viscosity of air \\
\hline$\lambda E$ & Latent heat of evaporation & $\chi$ & Thermal diffusivity of air \\
\hline $\mathrm{Nu}$ & Nusselt number & $\mathrm{z}\left(\mathrm{z}_{1}, \mathrm{z}_{2}, \mathrm{z}_{3}\right)$ & Vertical leaf layer (top, middle, bottom) \\
\hline
\end{tabular}

